\title{
Garças Reservoir trophic state dynamics: a 20-year synthesis
}

\author{
$\underline{\text { Denise C. Bicudo }}^{1,3},{ }^{\text {io Jaques E. Zanon }}{ }^{1}$, Carla Ferragut ${ }^{1}$, Luciane O. Crossetti ${ }^{2}$,
}

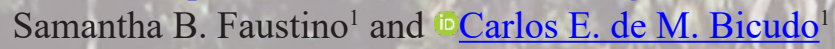

Received: 24 June 2019; accepted: 18 September 2019

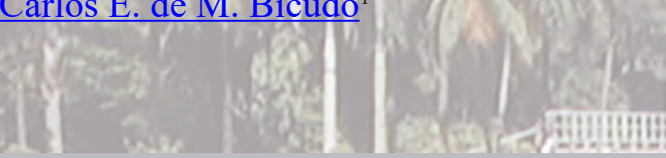

How to cite: Bicudo, D.C., Zanon, J.E., Ferragut, C., Crossetti, L.O., Faustino, B.S. \& Bicudo, C.E.M. 2020. Garças Reservoir trophic state dynamics: a 20-year synthesis. Hoehnea 47: e722019. http://dx.doi.org/10.1590/2236-8906-72/2019.

ABSTRACT - (Garças Reservoir trophic state dynamics: a 20-year synthesis). The Garças Reservoir history reveals a remarkable case of human impacts resulting from the urbanization pressure over the $20^{\text {th }}$ century. It is a shallow tropical system located in the Parque Estadual das Fontes do Ipiranga, a protected area within the city of São Paulo, São Paulo State, Brazil. Based on a comprehensive dataset (1997-2017), we evaluated the water quality temporal change using a trophic state index (TSI); in addition, we also verified whether the management procedures improved the water quality. Mechanical removal of macrophytes (1999) triggered an abrupt change from eutrophic-supereutrophic to the hypereutrophic state with feedback mechanisms. After five years (2005), a slowdown in the internal P loading process occurred, followed by the installation of the secondary wastewater treatment in the city zoo two years later (2007). Both processes promoted the beginning of water quality improvement. In 2011, TSI first dropped to supereutrophic state with the temporary diversion of the sewage effluent from the São Paulo State Department of Agriculture. This effluent was finally inactivated (2014) and the system sustained the supereutrophic state. TSI responded well to the historical key events related to the control of sewage effluents. After 11 years from the permanent impact of macrophytes removal, current results have demonstrated improved health of the system. It is absolutely necessary to improve the sewage treatment from the city zoo to continue the reservoir recovery considering that since 2014 it has been the only external phosphorous loading to Garças Reservoir. The history of Garças Reservoir can offer a better understanding of wrong management strategies and the vulnerability of tropical shallow systems to eutrophication.

Keywords: eutrophication, management, phosphorous, shallow reservoir, water quality

RESUMO - (Dinâmica do estado trófico do Lago das Garças: 20 anos de síntese). A história do Lago das Garças é um caso notável dos impactos humanos devidos à pressão da urbanização do século 20. Trata-se de uma represa tropical rasa localizada no Parque Estadual das Fontes do Ipiranga, área protegida situada na cidade de São Paulo, SP, Brasil. Com base em um banco de dados abrangente (1997-2017), nós avaliamos as alterações temporais da qualidade da água utilizando o índice de estado trófico (IET) e se as medidas adotadas de manejo melhoraram a qualidade da água. Em 1999, a remoção mecânica das macrófitas foi o gatilho para a mudança abrupta da represa do estado eutrófico-supereutrófico para hipertrófico, com mecanismos de retroalimentação. Após cinco anos (2005), ocorreu a desaceleração do aporte interno de P. Após dois anos (2007), houve a instalação da estação de tratamento secundário de esgoto na Fundação Parque Zoológico (2007). Ambos os eventos promoveram o início de uma melhora da qualidade da água. Em 2011, o IET passou para supereutrófico com a desativação temporária do efluente de esgotos provenientes da Secretaria de Agricultura e Abastecimento do Estado de São Paulo. Em 2014, este efluente foi totalmente desativado e o sistema manteve seu estado supereutrófico. Assim, o IET respondeu coerentemente aos eventos-chave relacionados com o controle dos efluentes de esgoto. Após 11 anos do impacto permanente da remoção das macrófitas, os resultados demonstraram a melhoria da qualidade da água da represa. Para prosseguir com a recuperação do Lago das Garças há necessidade absoluta de aperfeiçoar o sistema de tratamento secundário de esgoto proveniente do Zoológico, considerando que desde 2014 é o único efluente com aporte externo de fósforo para a represa. A história do Lago das Garças contribui para um melhor entendimento de estratégias errôneas de manejo e da vulnerabilidade de sistemas tropicais rasos à eutrofização.

Palavras-chave: eutrofização, fósforo, manejo, qualidade da água, represa rasa

1. Instituto de Botânica, Núcleo de Pesquisa em Ecologia, Avenida Miguel Estéfano 3687, 04301-012 São Paulo, SP, Brasil

2. Universidade Federal do Rio Grande do Sul, Instituto de Biociências, Departamento de Ecologia, Avenida Bento Gonçalves 9.500, 91549-000 Porto Alegre, RS, Brasil

3. Corresponding author: denisecbicudo@gmail.com 


\section{Introduction}

Freshwater systems are among the most threatened ecosystems worldwide despite being essential natural resources (Dudgeon at al. 2006, Vörösmarty et al. 2010, Moss 2010). Among the anthropogenic impacts, eutrophication is a widespread problem impairing the water multiple uses, maintenance of aquatic biodiversity, and human health (Davidson \& Jeppesen 2013, Cumming et al. 2015).

Urban reservoirs are, in particular, very vulnerable to human impacts since they integrate and accumulate material and pollutants from the drainage basin and receive discharges of nutrients leading to water quality deterioration (Branco \& Senna 1996, Figueredo \& Giani 2001, Dong et al. 2008, Fontana et al. 2014, Zorzal-Almeida et al. 2017). Moreover, shallow systems are usually more susceptible to eutrophication due to the water-sediment interaction and feedback mechanisms that intensify the system resistance to restoration efforts (Søndegaard et al. 2003, Bicudo et al. 2007).

Garças Reservoir history reveals a remarkable case of human impacts resulting from the urbanization pressure over the $20^{\text {th }}$ century. It is an urban system located in the Parque Estadual das Fontes do Ipiranga preservation area, surrounded by the São Paulo Metropolitan Region. It was originated from a former water supply reservoir built in 1894 to meet the city increasing demand for drinking water and was used for this purpose until 1928. CostaBöddeker et al. (2012) provided the eutrophication history of the reservoir during c. 110 years based on a paleolimnological study and land-use records (1894 to 2005). According to Costa-Böddeker et al. (2012), the reservoir experienced a deep decline in its water quality triggered by untreated sewage loads from the city zoo and further source of untreated domestic effluent from the São Paulo State Department of Agriculture.

In 1997, it was initiated a monthly monitoring program of the Garças Reservoir water quality. Based on a temporal series of 8 years (1997-2004), two contrasting limnological phases were characterized, i.e. before and after the mechanical removal of the macrophyte Eichhornia crassipes (Mart.) Solms, which caused an abrupt change to the hypertrophic state with the persistence of cyanobacterial blooms (Bicudo et al. 2007) and reduction (average 37\%) of phytoplankton species (Crossetti et al. 2008). More recently, a 20-year study (1997-2017) reported the invasion of the dinoflagellate Ceratium furcoides (Levander) Langhans and the environmental variables that contributed to its establishment and ecological success (Crossetti et al. 2019).

Such long-term monitoring measures a lot of variables and can hamper public understanding and management decision making. In order to mitigate such an issue, trophic state indexes (TSI) have been developed and improved since the 70s. Aiming at aquatic productivity and eutrophication measurements, the TSIs compose truthful health information on ecosystem. Particularly in São Paulo State, Lambarelli (2004) developed a TSI that has been widely used and is based on the classic Carlson's TSI (Carlson 1977) with some updates considering the tropical reservoir dynamics.

Over these last 20 years (1997-2017), Garças Reservoir has undergone environmental changes including management actions such as macrophytes harvesting, sewage diversion, and construction of a secondary wastewater treatment plant in the city zoo. Based on this comprehensive dataset, we aimed at evaluating (1) the water quality temporal change using a trophic state index (TSI), and (2) whether the management procedures adopted up to now have improved the water quality. The TSI tool has been broadly used in monitoring studies for allowing comparison of ecosystems productivity and providing an initial approach to determine the extent of cultural eutrophication (Carlson 1977, Salas \& Martino 1991, Lamparelli 2004, Cunha et al. 2013).

\section{Material and methods}

Study Area - Garças Reservoir (2338'40.6"S, $\left.46^{\circ} 37^{\prime} 28.0^{\prime \prime} \mathrm{W}\right)$ is a shallow tropical system located in the Parque Estadual das Fontes do Ipiranga - a protected area of the Atlantic Rain Forest within the city of São Paulo, São Paulo State, southeastern Brazil (figure 1). It was formed from a larger water supply reservoir (Campanário Reservoir) by damming the Campanário creek to meet the increasing demand for drinking water in 1894. Starting in $\sim 1917$, Campanário Reservoir was divided into five smaller water bodies, having the Garças Reservoir remained as the main system. The eutrophication process began with untreated sewage loadings from the city zoo (1958) and additional untreated sewage input from the São Paulo State Department of Agriculture (1975) (Costa-Böddeker et al. 2012). A drastic increase in allochthonous nutrients $(\mathrm{N}, \mathrm{P})$ led to the highest 


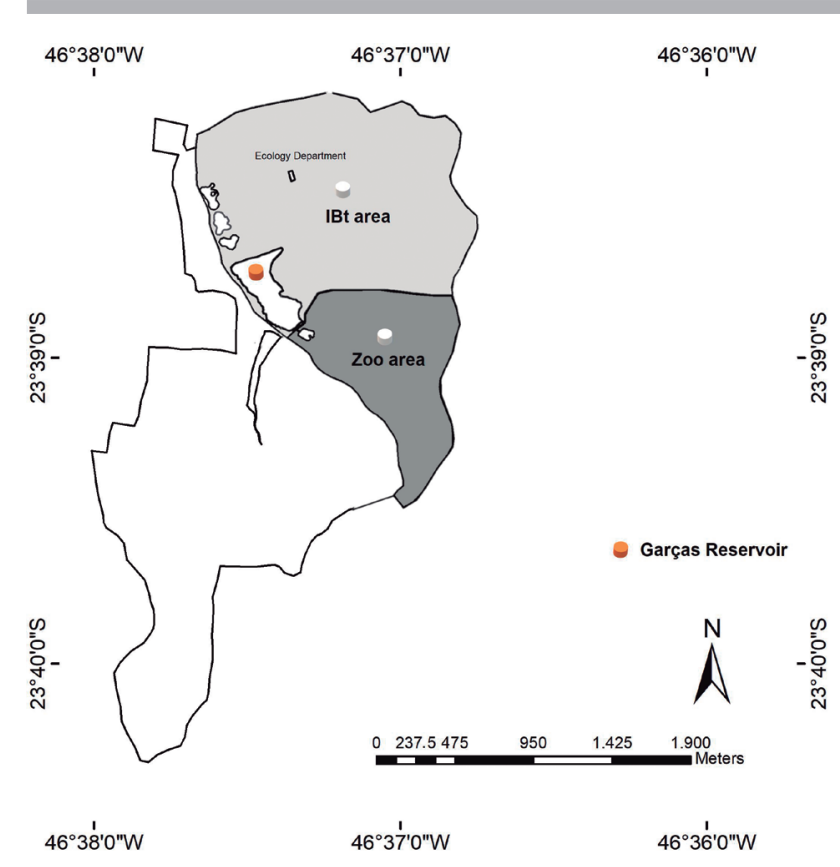

Figure 1. Map of the Parque Estadual das Fontes do Ipiranga (PEFI) area showing location of Garças Reservoir, the Institute of Botany (IBt), and the City Zoo areas, São Paulo, São Paulo State, Brazil.

macrophyte proliferation, with plants occupying $40-70 \%$ of the water surface causing mosquitoes proliferation in the reserve. Local authorities ordered the mechanical removal of all the macrophyte cover, which was later on carried out within two months (September/1999), triggering an abrupt change of Garças Reservoir from eutrophic to hypereutrophic state with permanent cyanobacteria blooms (Bicudo et al. 2007). In 2014, it occurred the invasion of Ceratium furcoides due to disturbing events sufficient to break the continuous dominance of cyanobacteria blooms (Crossetti et al. 2019). Further information on climate, morphometric features and limnological changes in the reservoir are available in Bicudo et al. (2007) and Crossetti et al. (2019).

Data sampling - We performed the samplings monthly over 20 consecutive years (1997-2017), always in the morning at the deepest site of the reservoir and collected the water samples using a van Dorn sampler and transferred to acid-rinsed bottles. We determined water transparency using a Secchi disk, total phosphorus (TP) concentration according to Valderrama (1981), and chlorophyll-a concentration corrected for pheophytin using 90\% ethanol (Sartory \& Grobbelaar 1984).

Data analysis - We used an adaptation of Carlson's Trophic State Index (TSI) (Carlson 1977) proposed by Lamparelli (2004) for tropical reservoirs - an index elaborated from reservoirs located at the same area of our study (CETESB 2014). TSI uses the total phosphorus (TP), chlorophyll-a (Chl-a) content, and Secchi disk depth (SD) data to calculate the corresponding trophic index. This procedure resulted in a 20-year trophic state time-series data.

In order to find perceptive changepoints in this time-series, we searched for significant mean and variance changes over the data. This process can separate data in different segments in terms of means and variance alterations, a changepoint is the observation that separates different segments (Killick \& Eckley 2014). This procedure allowed to identify critical changes in the Garças Reservoir trophic dynamics and was performed using the changepoint package (Killick \& Eckley 2014) and the PELT algorithm (Hinkley 1970), which enables multiple changepoints detection. For this purpose, we used the R program (R Core Team 2019).

After detecting critical changepoints in the data, we examined those with an analysis that deals with fitting piecewise terms (segments) in a regression model called piecewise (or segmented) regression. This type of regression considers one or more breakpoints as true parameters of the model and identifies potential time points that show significant change. The potential break-points are identified in the model due to a so-called "nuisance parameter". As a consequence, standard statistical tests do not apply (Muggeo 2008). In other words, we cannot use the p-value returned through classical tests. To mitigate this, we used the Davies test (Davies 1977) to verify significant differences between the slopes of each segment. It is worth mentioning that the Davies test is not aimed at obtaining the estimate of the break-point, it tests for a non-zero difference-in-slope parameter of a segmented relationship. For this purpose, we used segmented package (Muggeo 2008), also in R program (R Core Team 2019).

\section{Results}

The water quality of Garças Reservoir varied throughout the study period. During the first three years (1997-1999), the system maintained eutrophic and supereutrophic states (TSI between 59.1 and 67.0 without SD). From 2000 to 2011, Garças Reservoir was considered hypereutrophic (TSI $\geq 67.0$ without SD) and from 2011 until the end of the study period (2017) it returned to a supereutrophic state, except for 
2013 (figure 2). From the year 2000 on, the influence of Secchi disk depth on the index-wide behavior started to increase, having decreased again only during the last three years (2015-2017) (figure 2).

The behavior of the three limnological variables (Chl-a, TP and SD) used to estimate TSI also demonstrated great variation during the entire period (figure 3). Considering the whole period, TP concentrations ranged from 37.77 to $979.68 \mu \mathrm{g} \mathrm{L}^{-1}$ (172.44 - mean value), Chlo-a from 11.77 to 1323.63 $\mu \mathrm{g} \mathrm{L}^{-1}$ (156.60 - mean value), and SD ranged from 0.05 to $1.7 \mathrm{~m}$ (0.41 - mean value) (table1). Chlorophyll-a and total phosphorus concentrations presented similar variation, with a rapid increase of both variables at the end of 1999. However, a distinct TP increase occurred in 1999, 2001, at the end of 2002, and across the years 2003 to 2005; subsequently, both variables kept the same relative behavior. Secchi disk depth showed an abrupt decrease during the winter of 1999 and remained with relatively low values until 2010 when it started to increase again (figure 3 ).

The changepoint analysis identified only one point dividing the TSI time series into two segments (orange lines in figure 4a). These segments represent significant mean and variance changes in the TSI values over the time series. Following the same logic, we identified in each segment a new changepoint to access new mean changes in the data. We observed a mean increase ( 64 to 71 , figure $4 a$ ) followed by a mean decrease ( 74 to 67 , figure $4 \mathrm{~b}$ ) and finally a stable mean value (67, figure $4 \mathrm{c})$. This information was important to the use of piecewise regression. The first mean change occurred in August of 1999, and we used that first point as a possible breakpoint in the breakpoint (segmented) regression. Still, the breakpoint identified through the regression occurred in October of 2001. This means that we identified a significant TSI increase followed by a significant decrease (figure $4 b$ ), which was demonstrated through a positive regression coefficient (Time $=0.29$ ) followed by a negative coefficient (U1.Time $=-0.34$ ) (table 2). One can notice the "not applicable (NA)" term as the P value for U1.Time term (table 2). As previously discussed, the reason is that standard methods do not apply. The Davies test was significant, which provided us with had solid regression coefficients.

Figure 5 presents a synthesis of the TSI interannual variation. As we can see, the trophic state index of 2017 is very similar to the trophic state of 1997 (very close to the hypereutrophic threshold). In contrast, along the 2000-2010 period, TSI increases and the hypereutrophic state predominates. Starting in 2011 (except for 2013), TSI decreases to the supereutrophic state. The highest change in TSI occurred after phase II (April/1998-Sep./1999); thereafter, more pronounced changes occurred along different events reported during the study (table 1 and table 3). In particular, we observed the strong influence of the zoo secondary sewage treatment (STS Zoo in figure 5) as revealed in a gradual decrease in all of the values of the variables (table 1). Over the last period (2014-2017), we observed the lowest values of TSI, chlorophyll-a, and total phosphorus concentrations (table 1) in the time-series.

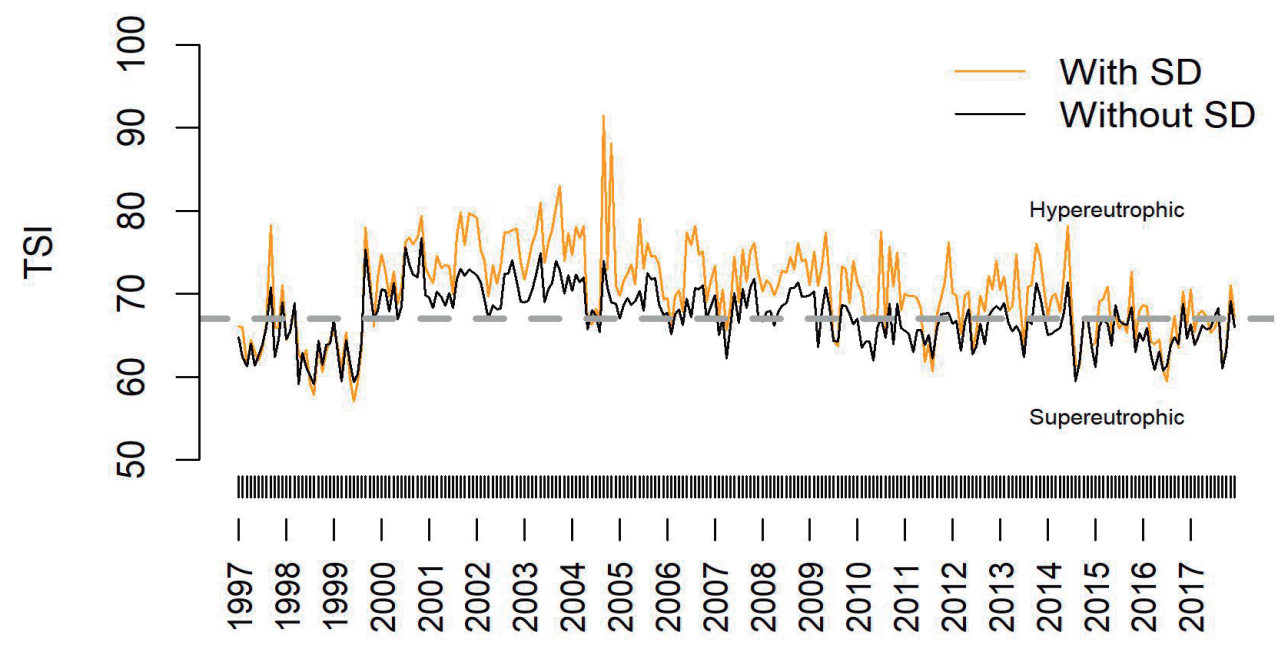

Figure 2. Changes in the trophic state of Garças Reservoir during the 20-year study. Trophic state index (TSI) calculated including Secchi disk depth - SD (orange line) and excluding it (black line). 


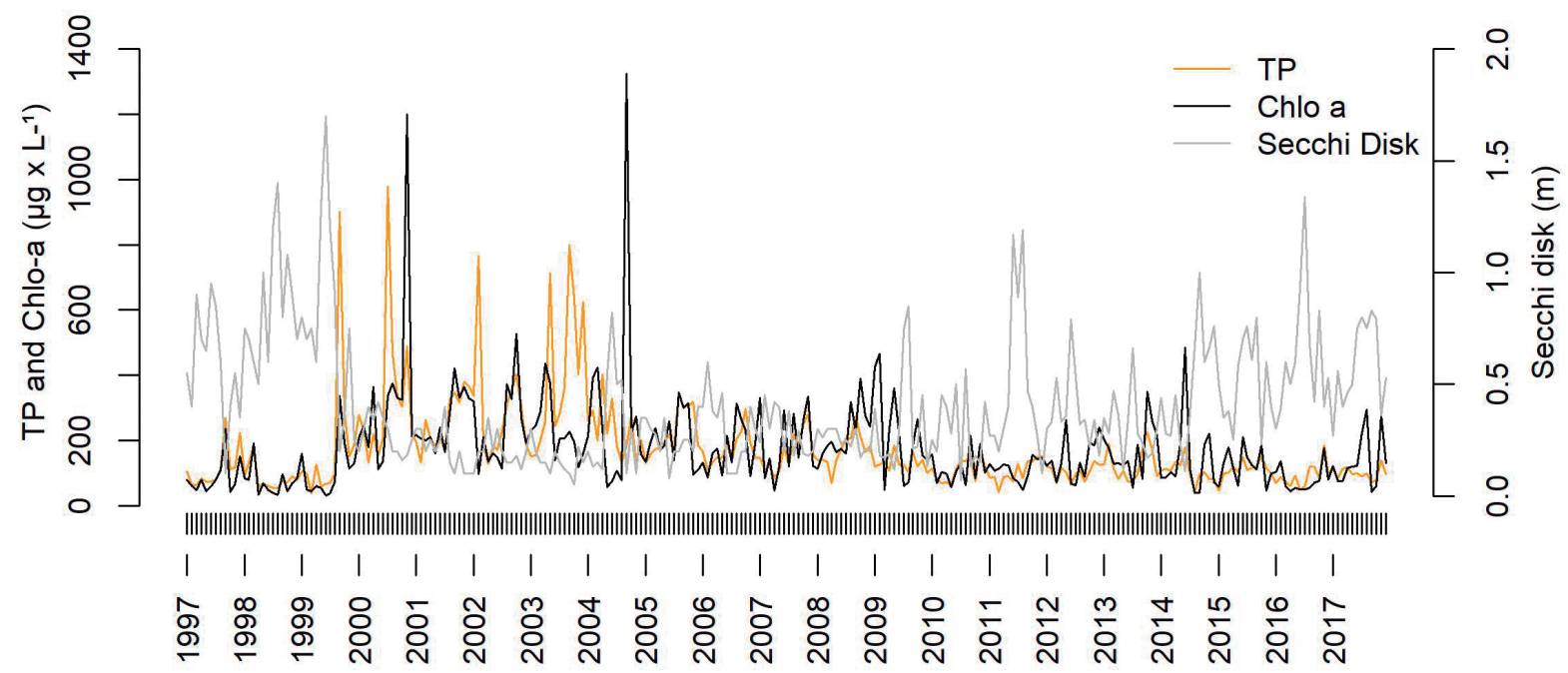

Figure 3. Raw values of limnological variables used to estimate the trophic state index (TSI). (TP: total phosphorus, Chlo-a: phytoplankton's biomass, Secchi disk: water transparency).
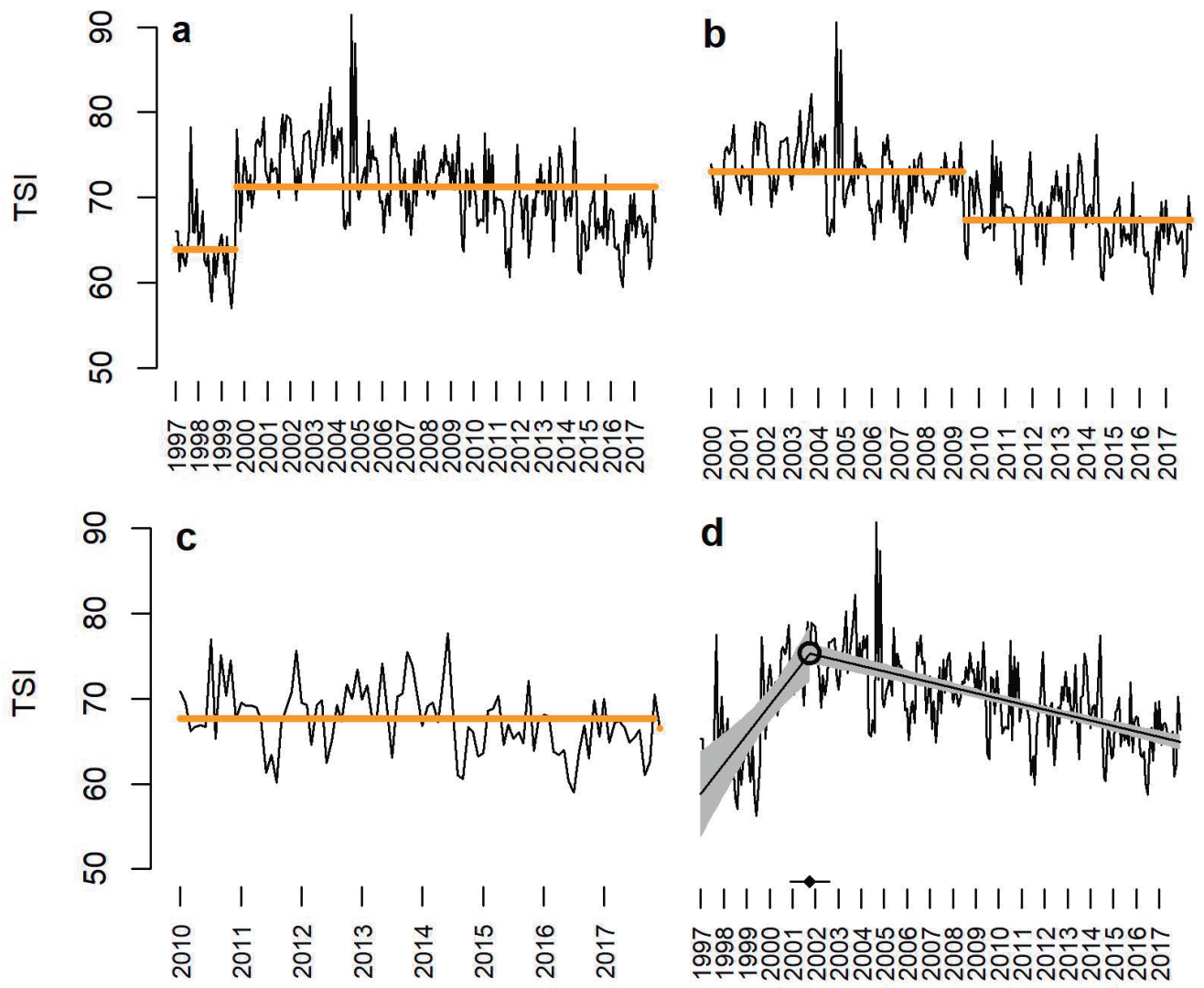

Figure 4 Changepoint and trends of trophic state index (TSI) data at Garças Reservoir. The black lines denote the observed values. a) orange straight lines symbolize two segments identified by the changepoint procedure, b) other two segments identified by the changepoint procedure, c) just one segment, no changepoint present and d) Solid line with gray bands denotes the trend and the confidence interval at 0.95 estimated by the segmented regression and the black dotted line represents the breakpoint (October/2001) and its confidence interval. 
Table 1. Limnological variables and Trophic State Index (TSI) of Garças Reservoir in the 20-year study. [- São Paulo, São Paulo State, Brazil. Gray shadow highlights mean values of variables for each phase and management event [- and + means absence and presence of STS Zoo (secondary sewage treatment) respectively; SPDA: means the deactivation of the sewage disposal of the São Paulo Agricultural Department].

\begin{tabular}{lccccc} 
Period & & Total P $\left(\mu \mathrm{g} \mathrm{L}^{-1}\right)$ & Chl-a $\left(\mu \mathrm{g} \mathrm{L}^{-1}\right)$ & Secchi $(\mathrm{m})$ & TSI \\
\hline Total & Min & 37.77 & 11.76 & 0.05 & 57.02 \\
Jan/1997 - Dec/2017 & Mean & 172.44 & 156.60 & 0.40 & 70.29 \\
Fase I & Max & 979.67 & 1323.62 & 1.70 & 91.47 \\
\multirow{2}{*}{ Jan/1997 - Mar/1997 } & Min & 62.09 & 21.05 & 0.10 & 61.36 \\
\multirow{2}{*}{ Fase II } & Mean & 118.48 & 74.78 & 0.60 & 65.91 \\
& Max & 269.22 & 218.31 & 0.95 & 78.24 \\
Apr/1998 - Sep/1999 & Min & 37.77 & 11.76 & 0.50 & 57.02 \\
STS Zoo - & Mean & 74.75 & 40.93 & 0.95 & 61.89 \\
Before Oct/2007 & Max & 126.71 & 140.82 & 1.70 & 65.63 \\
\multirow{2}{*}{ STS Zoo + } & Min & 37.77 & 11.76 & 0.05 & 57.02 \\
\multirow{2}{*}{ Oct/2007 - Jan/2014 } & Mean & 224.69 & 182.62 & 0.39 & 71.50 \\
SPDA \& STS Zoo & Max & 979.67 & 1323.62 & 1.70 & 91.47 \\
Feb/2014 - Dec/2017 & Min & 40.83 & 28.14 & 0.07 & 60.65 \\
& Mean & 127.71 & 146.44 & 0.34 & 70.48 \\
\hline
\end{tabular}

Table 2. Meaningful coefficients of the linear terms. Time: slope for the first segment. U1.Time: slope for the second segment.

\begin{tabular}{lcccc}
\hline & Estimate & Std. Error & t value & $\mathrm{P}$ \\
\hline Intercept & 59.27 & 2.61 & 22.71 & $<0.01$ \\
Time & 0.29 & 0.07 & 4.45 & $<0.01$ \\
U1.Time & -0.34 & 0.07 & -5.26 & NA \\
\hline
\end{tabular}

Davies test P-value $<0.01$

\section{Discussion}

Garças Reservoir is part of long-term ecological research (LTER) and has been well investigated over the years. On the basis of a 20-year data, we observed a small improvement in thehealth of the system.

The water quality of the system gradually has decreased since the city zoo construction (1958) in a headspring area located upstream Garças Reservoir, and further with the installation of the Department of Agriculture (1975), both with no adequate sanitation and contributing to high sewage loadings (table 3 ). As discussed by Bicudo et al. (2007), the eutrophication led to seasonal cyanobacterial blooms, the fast growth of water hyacinth (Eichhornia crassipes), and a huge proliferation of mosquitoes. As a measure to control the mosquitoes, most of the macrophytes were mechanically removed within a few months during the period of cyanobacterial bloom (table 3 ). After such a controversial strategy, Garças Reservoir shifted in a feedback mechanism with internal phosphorus loading and permanent cyanobacterial blooms, jumping to an "irreversible degraded state". The TSI captured such an abrupt change (transition 1999-2000, figure 2) clearly showing a jump to the hypereutrophic state. Bicudo et al. (2007) presented a comprehensive discussion of such process synthesizing in distinct limnological phases (I, II, and III, see reference) and the consequences of such action.

The acceleration of eutrophication occurred at the end of 1999 with the process of self-eutrophication (internal P loading). This period represents the 


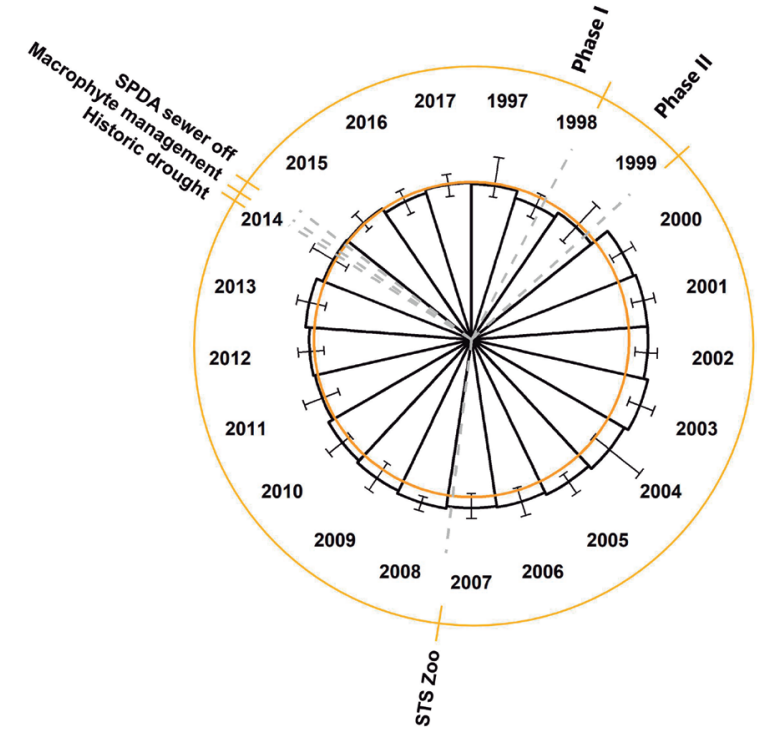

Figure 5. Mean and standard deviation of Garças TSI inter-annual and intra annual. (Inner orange circle represents the threshold between eutrophic and hypereutrophic state, STS: Secondary Sewage Treatment Station, SPDA: means the deactivation of the sewage disposal from the São Paulo Agricultural Department). beginning of our time series and includes more than 15 years of post-disturbance data, which provided us with an excellent opportunity to investigate the system response after such extreme event (Turner et al. 2006, Muller et al. 2010), as well as a long-term baseline which allowed to detect change and measure ecosystem responses to disturbance (Buma 2015).

The event of macrophytes removal (1999) caused a significant increase in the TSI mean values leading to a switch to a more turbid state, increased phosphorus concentrations, and feedback mechanisms (Bicudo et al. 2007). This reverberated into a TSI increase until the end of 2001 and the beginning of 2002, as evaluated through the point break regression (figure 5). Years after the abrupt change event, the TSI started to decrease. This can be related to some management events in the system history (tables 1 and 3). We highlight the importance of secondary wastewater treatment in the city zoo (started in October 2007). Moreover, it has most likely occurred a slowdown in the internal $\mathrm{P}$ loading process since 2005, as indicated by the lower surface $\mathrm{P}$ values in the time-series

Table 3. Key historical events in Garças Reservoir São Paulo, São Paulo State, Brazil.

\begin{tabular}{lcc}
\hline Period & Key events & Source \\
\hline 1894 & $\begin{array}{c}\text { Construction of the former water supply reservoir } \\
\text { (Campanário Reservoir) }\end{array}$ & $\begin{array}{c}\text { Costa-Böddeker et al. (2012) } \\
\text { Division of the previous water supply reservoir into five } \\
\text { water bodies. Garças Reservoir remained as the main } \\
\text { system }\end{array}$ \\
$\begin{array}{cc}\text { City zoo construction (sewage loadings) } \\
1917\end{array}$ & $\begin{array}{c}\text { Cinstallation of São Paulo State Department of Agriculture - } \\
1975\end{array}$ & SPDA (sewage loadings).
\end{tabular}

$1997-2017$

Monthly water monitoring program

1994-1998

Water hyacinth (Eichhornia crassipes) proliferation (covering $40-70 \%$ of water surface) and high proliferation of mosquitoes (Mansonia sp.).

June-September/1999

October/2007

March/2010-May/2011

February/2014

July/2014

September-November/2014

Macrophytes removal (3100 $\mathrm{m}^{3}$ of plants). Beginning of hypertrophic phase and permanent cyanobacterial blooms.

Installation of secondary wastewater treatment in the city zoo.

Temporary diversion of sewage effluent from the São Paulo State Department of Agriculture (SPDA).

Closure of SPDA and inactivation of its sewage effluent

Macrophyte stand management near the Zoo

Interruption in the sewage inflow from city zoo tributary during 3 months caused by the historic drought in São Paulo State.

September/2014
Present study

Bicudo et al. (2007) and the present study

Crossetti et al. (2019) 
(figure 3) and the decrease in bottom soluble reactive phosphorus with the increase in bottom oxygen levels (DCB, unpublished data). Therefore, after 2007, the combination of both processes promoted the beginning of the water quality improvement. From 2008 on, a sharp limnological change has also been demonstrated with the replacement of the cyanobacteria dominance from Microcystis aeruginosa (Kützing) Kützing to Cylindrospermopsis raciborskii (Woloszýnska) Seenayya \& Subba Raju (Crossetti et al. 2019).

Water transparency was also among the variables that were most affected by the water hyacinth removal (Bicudo et al. 2007) and throughout the events in the time-series, and can provide fruitful insights on the system equilibrium (Scheffer 1990). We observed that the irreversible turbid phase may have started to reverse since 2011, especially over the last five years (2013 to 2017) (figures 2-3). Undoubtedly, as stated by Crossetti et al. (2019), the replacement of dense cyanobacterial blooms with other phytoplankton species, such as the invasive Ceratium furcoides, might have contributed to higher transparency levels.

In 2011, TSI first dropped to the supereutrophic state (figures 2c, 5a) as a consequence of the previous actions and the temporary diversion of the sewage effluent from the São Paulo State Department of Agriculture (table 3). The exceptional increase in TSI in 2013 was a response to the historical drought during the period 2013-2014 in southeastern Brazil (ANA 2015). In 2014, the sewage effluent was finally inactivated; the system sustained the supereutrophic state and all variables revealed an improvement of the system health (table 1).

The TSI captured the vulnerability of this shallow tropical reservoir to wrong management actions (Bicudo et al. 2007) and the prolonged negative effect of the self-eutrophication to recovery (Jeppensen et al. 2003, 2005). Moreover, the TSI was sensitive to the historical key events related to the control of sewage effluents.

Summarizing, 11 years after the permanent impact of macrophytes removal (1999), current results demonstrated an improvement in the system health. The slowdown of the internal $\mathrm{P}$ loading process, in addition to the secondary sewage treatment from the zoo city and the sewage inactivation from the State Department of Agriculture, led to the maintenance of the supereutrophic state. It is important to emphasize that the secondary sewage treatment removes the biodegradable organic matter (in solution or suspended) and suspended solids, however, it does not remove dissolved nutrients (phosphorus and nitrogen). Therefore, in order to continue the reservoir recovery, it is absolutely necessary to improve the sewage treatment from the city zoo, considering that since 2014 it has been the only external phosphorous loading to Garças Reservoir.

As a consequence of the urbanization pressure, the history of Garças Reservoir can provide us with a better understanding of wrong management strategies and the eutrophication process in tropical systems. The key measure required for the prevention of water deterioration is the control of external nutrient loading, including point and non-point source pollution and management planning.

\section{Acknowledgments}

We would like to thank the undergraduate and graduate students very sincerely, as well as the technicians, for their continuous and valuable support in the field and laboratory over these many years. Authors are indebted to FAPESP (Fundação de Amparo à Pesquisa do Estado de São Paulo) and CNPq (Conselho Nacional de Desenvolvimento Científico e Tecnológico) for providing several funds and grants over these years. DCB and CEMB thank CNPq for Research Fellowships (310404/2016-9 and 305031/2016-3) and JEZ thanks FAPESP for the Postdoctoral Fellowship (2018/18896-4).

\section{Literature cited}

ANA (Agência Nacional de Águas). 2015. Conjuntura dos recursos hídricos 2014: encarte especial sobre a crise hídrica. In: Águas, A.N.D. (ed.), Brasília, pp. 1-30.

Bicudo, D.C., Fonseca, B.M., Bini, L.M., Crossetti, L.O., Bicudo, C.E.M. \& Araújo-Jesus, T. 2007. Undesirable side-effects of water hyacinth control in a shallow tropical reservoir. Freshwater Biology 52: 1120-1133.

Branco, C.C., \& P.A.C. Senna. 1996. Phytoplankton composition, community structure and seasonal changes in a tropical reservoir (Paranoá Reservoir , Brazil). Algological Studies 81: 69-84.

Buma, B. 2015. Disturbance interactions: characterization, prediction, and the potential for cascading effects. Ecosphere 6: 1-15.

Carlson, R.E. 1977. A Trophic State Index for Lakes. Limnology and Oceanography 22: 361-369.

CETESB (Companhia Ambiental do Estado de São Paulo). 2014. Relatório de qualidade de águas interiores do Estado de São Paulo. Companhia de Tecnologia de Saneamento Ambiental, São Paulo.

Fonte: Marca d'água - primeira página - Lago das Ninfeias - Jardim Botânico de São Paulo

Acervo iconográfico do Instituto de Botânica 
Costa-Böddecker, S., Bennion, H., Araújo-Jesus, T.A., Albuquerque, A.L.S., Figueira, R.C.L. \& Bicudo, D.C. 2012. Paleolimnologically inferred eutrophication of a shallow, tropical, urban reservoir in southeast Brazil. Journal of Paleolimnology 48: 751-766.

Crossetti, L.O., Bicudo D.C., Bini, L.M., Dala-Corte, R.B., Ferragut, C. \& Bicudo, C.E.M. 2019. Phytoplankton interactions and invasion by Ceratium furcoides are influenced by extreme drought and water-hyacinth removal in a shallow tropical reservoir. Hydrobiologia 831: 71-85.

Crossetti, L.O. \& Bicudo, C.E.M. 2008. Phytoplankton as a monitoring tool in a tropical urban shallow reservoir (Garças Pond): the assemblage index application. Hydrobiologia 610: 161-173.

Cumming, B.F., Laird, K.R., Gregory-Eaves, I., Simpson, K.G., Sokal, M.A., Nordin, R.N. \& Walker, I.R. 2015. Tracking past changes in lakewater phosphorus with a 251-lake calibration dataset in British Columbia: tool development and application in a multiproxy assessment of eutrophication and recovery in Osoyoos Lake, a transboundary lake in Western North America. Frontiers in Ecology and Evolution 3: 1-18.

Cunha, D.G.F., Calijuri, M.C. \& Lamparelli, M.C. 2013. A trophic state index for tropical/subtropical reservoirs (TSItsr). Ecological Engineering 60: 126-134.

Davidson, T.A. \& Jeppesen, E. 2013. The role of paleolimnology in assessing eutrophication and its impact on lakes. Journal of Paleolimnology 49: 391-410.

Davies, R.B. 1977. Hypothesis testing when a nuisance parameter is present only under the alternative. Biometrika 64: 33-43.

Dong, X., Bennion, H., Battarbee, R., Yang, X., Yang, H. \& Liu, E. 2008. Tracking eutrophication in Taihu Lake using the diatom record: potential and problems. Journal of Paleolimnology 40: 413-429.

Dudgeon, D., Arthington, A.H., Gessner, M.O., Kawabata, Z., Knowler, D., Lévêque, C., Naiman, R.J., Prieur, R.A.H., Soto, D. \& Stiassny, M.L.J. 2006. Freshwater biodiversity: importance, threats, status and conservation challenges. Biological Reviews 81: 163-182.

Figueredo, C.C., \& Giani, A. 2001. Seasonal variation in the diversity and species richness of phytoplankton in a tropical eutrophic reservoir. Hydrobiologia 445: 165-174.

Fontana, L., Albuquerque, A.L.S., Brenner, M., Bonotto, D.M., Sabaris, P.P., Pires, M.A.F., Cotrim, M.E.B. \& Bicudo, D.C. 2014. The eutrophication history of a tropical water supply reservoir in Brazil. Journal of Paleolimnology 51: 29-43

Hinkley, D.V. 1970. Inference about the change-point in a sequence of random variables. Biometrika 56: 1-17.

Jeppesen, E., Sondergaard, M., Jensen, J.P. \& Lauridsen, T.L. 2003. Recovery from eutrophication-restoration of eutrophic lakes: a global perspective. In: M. Kumagai \& W.F. Vincent (eds.). Freshwater management global versus local perspectives, pp. 135-151.
Jeppesen, E., Sondergaard, M. \& Jensen, J.P. 2005. Lake response to reduced nutrient loading - an analysis of contemporary long-term data from 35 case studies. Freshwater Biology 50: 1747-1771.

Killick, R. \& Eckley, I.A. 2014. Changepoint: An R Package for Changepoint Analysis. Journal of Statistical Software 58.

Lamparelli, M.C. 2004. Graus de trofia em corpos d'água do Estado de São Paulo: avaliação dos métodos de monitoramento. Tese de Doutorado, Universidade de São Paulo, São Paulo.

Moss, B. 2010. Ecology of freshwaters: a review for the twenty-first century. John Wiley \& Sons Ltd, Chichester.

Muggeo, V.M.R. 2008. Segmented: an R package to fit regression models with broken-line relationships. $\mathrm{R}$ News 8: 20-25.

Muller, F., Baeddler, C., Schubert, H. \& Klotz, S. 2010. Long-term ecological research: between theory and application. Springer, Dordrecht.

R Core Team. 2019. R: a language and environment for statistical computing. R Foundation for Statistical Computing, Vienna.

Salas, H.J. \& Martino P.A. 1991. A simplified phosphorous trophic state model for warm-water tropical lakes. Water Research 25: 1341-1350.

Sartory, D.P. \& Grobbelaar, J.U. 1984. Extraction of chlorophyll a from freshwater phytoplankton for spectrophotometric analysis. Hydrobiologia 114: 177-187.

Scheffer, M. 1990. Multiplicity of stable states in freshwater systems. Hydrobiologia 200/201: 475-486.

Søndegaard, M., Jensen, J.P. \& Jeppesen, E. 2003. Role of sediment and internal loading of phosphorus in shallow lakes. Hydrobiologia 506-509: 135-145.

Turner, M.G., Collins, S.L., Lugo, A.L., Magnuson, J.J., Rupp, T.S. \& Swanson, F.J. 2006. Disturbance Dynamics and Ecological Response: The Contribution of Long-Term Ecological Research. BioScience 53: 46-56.

Valderrama, J. C. 1981. The simultaneous analysis of total nitrogen and total phosphorus in natural waters. Marine Chemistry, 10: 109-122.

Vörösmarty, C.J., McIntyre, P.B., Gessner, M.O., Dudgeon, D., Prusevich, A., Green, P., Glidden, S., Bunn, S.E., Sullivan, C.A., Liermann, C.R. \& Davies, P.M. 2010. Global threats to human water security and river biodiversity. Nature 467: 555-561.

Zorzal-Almeida, S., Bicudo, D.C., Lamparelli, M.C., Faustino, S.B., Ferragut C. \& Bicudo C.E.M. 2017. Avaliação do Índice de Estado Trófico e sua aplicação na represa Guarapiranga em longa série temporal. In: C.E.M. Bicudo \& D.C. Bicudo (eds.). 100 anos da represa Guarapiranga: lições e desafios. CRV, Curitiba, pp. 401-428. 